\title{
Using an affinity analysis to identify phytoplankton associations
}

\author{
Weiju Zhu ${ }^{1}$, Zhaojian Ding ${ }^{1}$, Yangdong Pan $^{2}$, and Quanxi Wang ${ }^{3}$ \\ ${ }^{1}$ Qiongtai Normal University \\ ${ }^{2}$ Portland State University \\ ${ }^{3}$ Shanghai Normal University
}

January 20, 2022

\begin{abstract}
Phytoplankton functional traits can represent particular environmental conditions in complex aquatic ecosystems. Categorizing phytoplankton species into functional groups is challenging and time-consuming, and requires high-level expertise on species autecology. In this study, we introduced an affinity analysis to aid identification of candidate associations of phytoplankton from two datasets comprised of phytoplankton and environmental information. In the Huaihe River Basin with a drainage area of 270,000 km2 in China, samples were collected from 217 selected sites during the low-water period in May 2013; monthly samples were collected during 2006-2011 in a man-made pond, Dishui Lake. Our results indicated that the affinity analysis can be used to define some meaningful functional groups. The identified phytoplankton associations reflect the ecological preferences of phytoplankton in terms of light and nutrients acquisition. Advantages and disadvantages of applying the affinity analysis to identify phytoplankton associations are discussed with perspectives of their utility in ecological assessment.
\end{abstract}

\section{The names of authors:}

Weiju Zhu Zhaojian Ding Yangdong Pan Quanxi Wang

\section{Title}

\section{Using an affinity analysis to identify phytoplankton associations}

The affiliations and addresses of the authors

W. Zhu, D. Zhao

School of Science, Qiongtai Normal Universtiy, Haikou 571127, P. R. China

Tropical Biodiversity and Bioresource Utilization Laboratory, Qiongtai Normal University, Haikou, 571127, P. R. China

Corresponding author: zhuweijuqtnu@163.com

Yangdong Pan

Environmental Science and Management, Portland State University, Portland 97207, USA

Q. Wang

College of Life and Environmental Sciences, Shanghai Normal University, Shanghai 200234, P. R. China

Conflict of interest 
The authors declared that they have no conflicts of interest to this work. We declare that we do not have any commercial or associative interest that represents a conflict of interest in connection with the work submitted.

\begin{abstract}
Phytoplankton functional traits can represent particular environmental conditions in complex aquatic ecosystems. Categorizing phytoplankton species into functional groups is challenging and timeconsuming, and requires high-level expertise on species autecology. In this study, we introduced an affinity analysis to aid identification of candidate associations of phytoplankton from two datasets comprised of phytoplankton and environmental information. In the Huaihe River Basin with a drainage area of $270,000 \mathrm{~km}^{2}$ in China, samples were collected from 217 selected sites during the low-water period in May 2013; monthly samples were collected during 2006-2011 in a man-made pond, Dishui Lake. Our results indicated that the affinity analysis can be used to define some meaningful functional groups. The identified phytoplankton associations reflect the ecological preferences of phytoplankton in terms of light and nutrients acquisition. Advantages and disadvantages of applying the affinity analysis to identify phytoplankton associations are discussed with perspectives of their utility in ecological assessment.
\end{abstract}

Keywords Affinity analysis . Huaihe River Basin . Dishui Lake . functional groups; phytoplankton association

\title{
Introduction
}

Ecologists are facing challenges to decipher a rich amount of biological and environmental information embedded in an ecological community. The classification of a set of taxonomic units into functional groups based on morphology and species traits has been widely used in ecological research (Litchman \& Klausmeier, 2008; Usseglio-Polatera et al. 2000). If species are pooled into the same group based on similar morphological or physiological characteristics and developing ecological groups, that can help ecologists to better understand the interactions between biological communities and their environment. For example, stream macroinvertebrates have been categorized into functional feeding groups, such as scrapers, shredders, collector-gatherers, collector-filterers and predators. Logez et al. (2013) suggested that similar fish assemblage functional structures will be found in similar environmental conditions.

Categorizing phytoplankton by their traits and functions was attempted a few decades ago. Reynolds et al (2002) set a precedent in the classification of phytoplankton functional groups. Salmaso \& Padisák (2007) developed the Morpho-Functional Groups based on the phytoplankton morphological and functional characteristics, such as body size, mobility, nutrient requirements and other features. Kruk et al (2010) applied morphology-based functional groups (MBFG) approach to cluster phytoplankton organisms, and seven groups were defined according to the main morphological traits of phytoplankton such as cell volume, presence of flagella and the ratio of surface area and volume. However, there are still some challenges for phytoplankton ecologists to apply functional concepts in phytoplankton research. For example, phytoplankton communities can be extremely rich (Reynolds 2006) but may differ from region to region due to ecological factors. Classifying species into different functional groups requires a extensive amount of knowledge on the autecology of each species, and such information may not be readily available in the literature. Physiological data are not available for all phytoplankton species (Weithoff 2003), which limits our abilities for developing a priori functional classification (Mieleitner et al. 2008). On the other hand, environmental assessment of lakes using phytoplankton is urgently needed by water quality managers, especially in some rapidly developing regions such as China because of serious water pollution. A great deal of phytoplankton ecological studies have been conducted in Europe (EC Parliament and Council 2000), North America (Arhonditsis et al., 2004) and China (Deng et al., 2014). The implementation of water programs have generated an enormous amount of phytoplankton data with large spatial scales using standardized field protocols. How to effectively use these 'datasets' to enhance our current understanding of phytoplankton assemblages with relation to their environments and water resource management still remains challenging.

In order to provide a better understanding of the ecological information of phytoplankton associations, we introduce an affinity analysis called association rule for identifying phytoplankton associations. Association 
rule is a machine-learning method for discovering co-occurrence relationships among activities performed by specific individuals or groups in a large database using simple statistical performance measures. There have been many successful business applications for applying the method in finance, telecommunication, marketing, retailing and web analysis (Chen et al. 2005). Association rule is used to understand the purchase behavior of customers in retail. For example, people often purchased flowers and then cards, purchased milk and then eggs, so we can then call flower+cards or milk+eggs associations. This information is helpful for cross-selling, up-selling and discount plans. For phytoplankton, Aulacoseira subarctica, Aulacoseira islandica and Cyclotella meneghiniana, Cyclotellastelligera co-exist in softer-water lakes (Reynolds et al., 2002).

In ecological studies, we assume that each sampling site or sampling date is a 'transaction' in a business setting and each species is an item and then develop the associations. Many researches focus on phytoplankton spatial and temporal variations in lakes and rivers, and therefore this study identified phytoplankton associations from spatially and temporally datasets, respectively. The main objective of this study was to use affinity analysis to aid identification of the candidate associations of phytoplankton and then assess the relationships between the candidate phytoplankton associations and environmental factors using the redundancy analysis (RDA).

\section{Methods}

\section{Data preparation}

\section{River phytoplankton: a spatially dataset}

River phytoplankton data were collected as a part of the Water Pollution Control Program in the Huaihe River Basin (30 $\left.55^{\prime}-36^{\circ} 36^{\prime} \mathrm{N}, 111^{\circ} 55^{\prime}-121^{\circ} 25^{\prime} \mathrm{E}\right)$ (HRB). The basin, with a drainage area of $270,000 \mathrm{~km}^{2}$, is located between the Yangtze River and the Yellow River in China (Wang and Xia 2010). It forms a geographical separation between northern and southern China. Phytoplankton samples were collected from 217 randomly selected sites during the low-water period in May 2013 (Fig. 1). Detailed field and lab methods can be found in Zhu et al (2015). In each site, three cross-section transects were established. We measured in situenvironmental variables including water temperature (WT), pH, conductivity (Cond), turbidity and total suspend solids (TSS) using a portable HACHCDC40105. We also measured Secchi depth (SD), water depth, stream width, water velocity and elevation. Spectrophotometer (DR5000) was used to measure total phosphorus $(\mathrm{TP})$, total nitrogen $(\mathrm{TN})$ and chemical oxygen demand $\left(\mathrm{COD}_{\mathrm{Mn}}\right)$ according to standard methods(NEPAC 2002).

For phytoplankton, a 1L sample from the $0.5 \mathrm{~m}$ depth below surface was collected from three cross-section transects, respectively. After complete mixing, a 1L sample was preserved with 1\% Lugol's iodine solution immediately in the field and concentrated to $50 \mathrm{~mL}$ after sedimentation for $48 \mathrm{~h}$. After complete mixing, 0.1 $\mathrm{mL}$ of the concentrated sample was counted directly in a $0.1 \mathrm{~mL}$ counting chamber under a microscope at $400 \times$ magnification. Phytoplankton was identified according to the reference book by Hu \& Wei (2006). At least 400 algal units were counted in each sample. Phytoplankton biomass was expressed as wet biomass and was estimated for individual species by assigning a geometric shape similar to the shape of each phytoplankton species (Hillebrand 1999).

\section{Lake phytoplankton: a temporally dataset}

Monthly phytoplankton samples were collected during 2006-2011 to assess temporal variability of phytoplankton assemblages in a man-made pond. Dishui Lake ( $\left.30^{\circ} 53^{\prime} \mathrm{N}, 121^{\operatorname{deg}} 55^{\prime} \mathrm{E}\right)$ is located in Pudong New Area District, southeastern Shanghai, China (Fig. 1a). Detailed field and lab methods can be found in Zhu et al (2013). Eight sampling stations were selected in the lake (Fig. 1b). We measuredin situ environmental variables including water temperature (WT), $\mathrm{pH}$, conductivity (Cond), turbidity, total suspend solids (TSS) and Secchi depth (SD). Total phosphorus (TP), total nitrogen (TN), and chemical oxygen demand (COD $\mathrm{Mn})$ were measured according to standard methods.

\section{Data analysis}


We selected 38 species in HRB and 23 species in Dishui Lake, respectively, after excluding 'rare' taxa from analyses. The rare taxa were defined as those with average relative biomass $(\mathrm{RB})<0.5 \%$ and occurred at $<10$ sites/samples.

\section{Data format}

The dataset was formatted as an M x N matrix, where the row represents different sampling sites S1, S2, S3..., Sn and the column represents phytoplankton species G1, G2, G3... Gn. Each element [i,j] represents the occurrence of the species $\mathrm{j}$ in the sample $\mathrm{i}$ (Table 1 ).

\section{Association rule}

The matrix usually contains large amount of data, therefore data mining techniques are used to extract useful knowledge. We followed the association rule proposed by Agrawal et al (1993).

Association rule is intended to capture a certain type of dependence among species represented in the database. The rule is defined as an implication of the form G1->G2, for example, an association rule between species in the form of G1->G 2 which means species 1 is also very likely to be observed with species 2 to form an association $\{\mathrm{G} 1, \mathrm{G} 2\}$.

The significance of the association rule is measured via support and confidence. The support of rule G1- $>$ G2 is the percentage of G1 and G2 occurring together. Confidence of rule G1->G2 is merely an estimate of the conditional probability of G2 given G1. If the confidence of rule G1->G2 is 1 that means G1 occurs in a particular site then G2 should occur in that site, too.

First, the binary phytoplankton data for identifying phytoplankton associations were constructed (Table 1), "S" represents the sampling site or time series, "G" represents algae species. Secondly, the support of phytoplankton association was calculated. For instance, the association \{G1, G3\} has 18\% support because the species G1 and G3 occurs together in 2 of the 11 (Table 2). Finally, we calculated the confidence of each phytoplankton association (Table 3 ). For example, the confidence of the association $\{\mathrm{G} 1, \mathrm{G} 3\}$ is 0.5 because species 3 occurs at half of times that also containing species 1 .

We identified the phytoplankton associations based on both support $>=50 \%$ and confidence $>=0.8$.

All analyses were performed using R software (R Development Core Team 2013). Specifically, we used the R package 'arules' for the affinity analysis, 'vegan' for detrended correspondence analysis (DCA) and redundancy analysis(RDA) and 'packfor' for forward selection analysis (Oksanen et al., 2013; Hahsler et al., 2014; Dray et al., 2013).

\section{Results}

Almost one third taxa $(28.95 \%)$ occurred at $50 \%$ of all sites or more in the HRB (Table 4). five species (Cryptomonas erosa, Chroomonas acuta, Cyclotella meneghiniana, Scenedesmus quadricauda, Navicula cryptocephala ) occurred at more than $70 \%$ of the sites. Two Euglenophytes, two Chrysophytes and Pandorina morum occurred at less than $10 \%$ sites. Eighteen of 23 taxa were present in Dishui Lake during more than half of the sample dates (Table 4). Only five taxa had less than $50 \%$ occurrence (e.g. Carteria sp.,Amiphiprora sp., Cryptomonas ovata, Cyclotella sp., Melosira varians ).

\section{The phytoplankton associations in HRB and Dishui Lake}

Twelve phytoplankton associations in HRB were identified by combinations of two to three taxa (Table 5) based on support $>=50 \%$, and confidence values of $>=0.8$. All associations can be divided into three types: (1) The flagellate algae association (R01-1, R01-2, R01-9): pollution-tolerant species (e.g., Cryptomonas ovata and Cryptomonas erosa) co-existed; mixotrophic chrysophytes (e.g.,Chrumulina sp.) was observed to occur with Cryptomonas erosa, Chroomonas acuta, Chlamydomonas globosa from different taxon groups. (2) The diatoms with the flagellate algae association (R03-2, R05-2, R06-2, R07-2, R08-2, R10-2, R11-2 and R12-2): benthic diatoms with motility (e.g., Nitzschia palea ,Navicula cryptocephala) frequently co-occurred with the cryptophytes. It should be noted that a small centric planktonic diatom (Cyclotella meneghiniana 
) also occurred with the flagellate algae. (3) The diatoms association (R04-3: Nitzschia palea and Cyclotella meneghiniana).

Fifteen phytoplankton associations in Dishui Lake were identified by combinations of two to three taxa (Table 5). These associations can be divided into three types: (1) The flagellate algae association (L11-1): mixotrophic chrysophyte Chrumulina pygmaea was observed to occur with Chlamydomonas globosa. (2) The mixed association-diatoms or colonial green algae with the flagellate algae association: this association can be further divided into three smaller associations including mixotrophic chrysophyte Chrumulina pygmaeawith diatoms or green algae (L03-2, L07-2, L09-2, and L12-2), Chlamydomonas globosa with diatoms or green algae (L01-2, L02-2, L04-2, L05-2, L08-2, L10-2 and L13-2), and Chromulina pygmaea and Chlamydomonas globosa with diatoms or green algae (L14-2 and L15-2). (3) The diatoms with colonial green algae association (L06-3).

\section{Relationships between phytoplankton associations and environmental variables}

We analyzed the phytoplankton assemblages characterized with 12 phytoplankton associations in HRB using detrended correspondence analysis (DCA). DCA results showed that the maximum gradient length of the four axes was 2.63. Subsequently, we selected a redundancy analysis (RDA) to detect the relationship between phytoplankton associations and environmental factors (Fig. 2). Approximately $12 \%$ of the variance in phytoplankton associations can be explained by environmental factors (axis 1: 8\%, axis 2: $3 \%$ ). Forward selection in RDA identified six significant environmental factors (Fig. 2). Turbidity was positively correlated with axis 1, TN/TP ratio was negatively correlated with axis 1; Conductivity and TN positively correlated with axis 2 , stream order negatively correlated with axis 2 . Most of the mixed associations had a positive relationship with TN and turbidity except that association 3 displayed a positive relationship with conductivity and negative correlation with turbidity (Fig. 2). The flagellate algae association had a positive relationship with turbidity, DO and stream size while the diatom association was positively associated with TN(Fig. 2).

We used the 15 phytoplankton associations in Dishui Lake for detrended correspondence analysis (DCA) with the maximum gradient length of the four axes as 1.55 . RDA showed that $32 \%$ variance in phytoplankton associations can be explained by environmental factors: axis 1: $27 \%$, axis $2: 4.8 \%$. Forward selection in RDA identified three significant environmental factors (Fig. 3). Salinity and transparency were negatively correlated with axis 1; $\mathrm{pH}$ was negatively correlated with axis 2 . The mixed associations including Chromulina had a positive relationship with $\mathrm{pH}$ and transparency while the mixed associations including Chlamydomonas had a negative relationship with $\mathrm{pH}$ (Fig. 3). The flagellate associations positively correlated with salinity (Fig. 3).

\section{Discussion}

Comparing to the traditional phytoplankton functional groups development (Reynolds et al. 2002), affinity analysis is a method for rapidly finding phytoplankton associations from a large dataset. It has the advantage of time-saving and easy use, especially for new algae researchers in a region with limited ecological studies on local phytoplankton assemblages. So affinity analysis can be used as a first step to identify candidate phytoplankton associations.

The identified phytoplankton associations reflect the ecological preferences of phytoplankton including the resources acquisition (e.g., light and nutrients) and competitive abilities (e.g., r/K selection or C-S-R model) (Salmaso et al. 2015). Cryptomonas erosa andCryptomons ovata or Chroomonas acuta from the same family were often concurrent in HRB (Table 2). These species can benefit from both mixotrophy and phagotrophy, and also can tolerate high dissolved nutrients and limiting light conditions (Graham \& Wilcox, 2000; Kruk et al. 2012), and can avoid grazing by zooplankton. Some taxa from different divisions can form the associations such as diatom-cryptophytes. Diatom-cryptophytes associations are consistent with what Sommer et al (1986) suggested that Cryptophyceae and small centric diatoms developed together when nutrients were available and light increased in spring because of their small volume and high growth rate. Some of the identified phytoplankton associations can reflect the grazing pressure. The observed associations 
are consistent with the notion that both Scenedesmus and Selenastrum are more resistant to grazing than either Chlamydomonas or Ankistrodesmus, while the latter two taxa are better competitors in the absence of grazing (Drake 1993). Motile benthic diatoms such asNitzschia palea are concurrent with some planktonic algae. Benthic diatom motility offers a selective advantage on silty substrata, but it is also correlated with some ecological traits((Passy, 2007). Kawamura et al (2004) demonstrated that grazing pressure of gastropods had an influence on the Nitzschia species.

We performed a RDA for assessing the applicability of the identified phytoplankton associations in environmental assessment. In HRB, the light and TN were the best predictors of phytoplankton associations (Fig. 3 ). Our results are consistent with Mackay et al (2012) that the diatom-association was strongly with the TN nutrient. In Dishui Lake, the light and salinity were the best predictors for phytoplankton associations (Fig. 4). Chrysophytes are restricted to cold, oligotrophic conditions. Small Chromulina groups showed a different response to $\mathrm{pH}$ and water clarity, compared to the medium size Chlamydomonas groups (Fig. 4). The importance of $\mathrm{pH}$ as a primary factor affecting chrysophytes has been reported in studies from widely separated geographic regions. Chromulina and Chlamydomonas are both $r$-selected taxa, their small-medium body size and motility conferred by flagella are advantages and allow them to reduce sinking rate (Kruk et al. 2010). Compare the Chlamydomonas, theChromulina prefer the oligotrophic environments with an abundance of macrophytes (Thiago Rodrigues dos Santos1* Carla Ferragut, 2019). Compared to the river, more variance $(33 \%)$ in phytoplankton associations can be explained by different combinations of environmental factors in the man-made shallow lake. A lake is perceived to be relatively stable, that of a river, is characteristically graded from the origin to the river-mouth (Reynolds et al. 1994). Therefore, candidate phytoplankton associations are reasonable proxies for explaining environmental variables.

Binary data were used to construct the phytoplankton associations in this work, which ignores the abundance of phytoplankton species. Although binary data are commonly observed and analyzed in many application fields (Yamamoto \& Hayashi, 2015), some species which were not abundant potentially contributed much more to the analysis than those common taxa but we minimized the effects. The phytoplankton associations identified by affinity analysis should be viewed as candidate associations and each association should be carefully evaluated using ecological theories and concepts.

In essence, affinity analysis can be a useful method for finding the phytoplankton associations from the complex and informative dataset. It can explain some fraction of the variance from the both spatial and temporal algal assemblages distribution patterns, although their effectiveness varies differently in river and lake, depending on the gradients of environmental factors. Our results do not mean that the proposed method should replace the conventional ecological classifications of phytoplankton. The proposed method provides an alternative, especially for the regions where researches on phytoplankton assemblages are still limited. Affinity analysis remains to be tested in future research whether it is predicted better for phytoplankton associations than other classification systems.

\section{Acknowledgments}

The authors would like to thank the staff of Nanjing University for the sampling program in Huaihe River Basin and Nanhui Environmental Monitoring Central Station for the sampling program in Dishui Lake. The authors gratefully acknowledge anonymous reviewers. This project was supported by the National Key Special Project of Sci-tech for Water Pollution Control and Management (No.2012ZX07501002-003) and the Education Department of Hainan Province (Hnky2020-60) .

\section{Data Accessibility}

The data that supports the findings of this study are available as online: 4TU Research Data

Doi:10.4121/18487790

\section{References}

Agrawal R, Imielinski T, Swami A (1993) "Mining association rules between sets of items in large databases". 
In: Proceedings of the 1993 ACMSIGMOD International Conference on Management of Data. Washington, DC, USA: ACM Press, 207-216.

Arhonditsis GB, Winder M, Brett MT, Schindler DE (2004) Patterns and mechanisms of phytoplankton variability in Lake Washington (USA). Water Res, 38: 4013-4027. doi:10.1016/j.watres.2004.06.030

Chen YL, Tang K, Shen RJ, Hu YH (2005) Market basket analysis in a multiple store

environment. Decis Support Syst 40: 339-354. doi:10.1016/j.dss.2004.04.009

Deng J, Qin B, Paerl HW, Zhang Y, Ma J, Chen Y (2014) Earlier and warmer springs increase cyanobacterial (Microcystis, spp.) blooms in subtropical Lake Taihu, China. Freshw Biol 59: 1076-1085. doi:10.1111/fwb.12330 Drake JA, Flum TE, Witteman GJ, Voskuil T, Hoylman AM, Creson C, Kenny DA, Huxel GR, Larue CS, Duncan JR (1993) The construction and assembly of an ecological landscape. J Anim Ecol 62: 117-130. doi:10.2307/5487

Dray S, Legendre P, Blanchet G (2013) Packfor: Forward Selection with permutation (Canoco p.46). http://R-Forge.R-project.org/projects/sedar/

EC Parliament and Coincil (2000) Directive of the European Parliament and of the Council 2000/60/ EC Establishing a Framework for Community Action in the Field of Water Policy. European Commission, Luxembourg

Graham LE, Wilcox LW (2000) Algae. Prentice-Hall, Upper Saddle River, New Jersey

Hahsler M, Buchta C, Grun B, Hornik K (2014) Arules: Mining Association Rules and Frequent Itemsets. http://CRAN.R-project.org/package=arules

Hartmann H, Steinberg C (1989) The occurrence of silica-scaled chrysophytes in some central European lakes and their relation to $\mathrm{pH}$. Nova Hedwigia Beihefte 95: 131-158.

Hillebrand H (1999) Biovolume calculations for pelagic and benthic microalgae. J Phycol 35: 403-424. doi:10.1046/j.1529-8817.1999.3520403.x

Hu H, Wei Y (2006) The freshwater algae of China Systematics, taxonomy and ecology. Sciences Press, Beijing

Kawamura T, Takami H, Yamashita Y (2004) Effect of grazing by a herbivorous gastropod Homalopoma amussitatum, a competitor for food with post-larval abalone, on a community of benthic diatoms. J Shellfish Res 23: 989-993.

Kristiansen J (1975) On the Occurrence of the Species of Synura (Chrysophyceae). Verhandlungen Internationale Vereinigung Limnologie 19: 2709-2715.

Kristiansen J, Takahashi E (1982) Chrysophyceae: introduction and bibliography. In: Rosowski, J and Parker, B.(eds.) Selected papers in phycology, vol II Phycological Society of America, Lawrence, Kansas, pp: 698-704

Kruk C, Huszar VLM, Peeters ETHM, Bonilla S, Costa L, Lurling M, Reynolds CS, Scheffer M (2010) A morphological classification capturing functional variation in phytoplankton. Freshwater Biol 55: 614-627. doi: $10.1111 /$ j. 1365-2427.2009.02298.x

Kruk C, Segura AM (2012) The habitat template of phytoplankton morphology-based functional groups. Hydrobiologia 698: 191-202. doi: 10. 1007/s10750-012-1072-6

Leishman MR, Westoby M (1992) Classifying plants into groups on the basis of associations of individual traits-evidence from Australian semi-arid woodlands. J Ecol 80: 417-424. doi: 10. 2307/2260687

Lewis WM (1976) Surface/volume ratio: implications for phytoplankton morphology. Science 192: 885-887. doi: $10.1126 /$ science.192.4242.885 
Litchman, E.\& Klausmeier CA (2008) Trait-based community ecology of phytoplankton. Annu Rev Ecol Evol Syst 39: 615-639.

Logez M, Bady P, Melcher A, Pont D (2013) A continental-scale analysis of fish assemblage functional structure in European rivers. Ecography 36: 80-91.

NEPAC (The National Environmental Protection Agency of China) (2002) Standard methods for the examination of water and waste water, 4th ed. Chinese Environmental Science Press, Beijing.

Oberwinkler F (1993) Evolution of Functional Groups in Basidiomycetes.(Fungi).In Schulze ED and Mooney HA (eds), Biodiversity and Ecosystem Function. Ecological Studies. Springer-Verlag, Berlin, pp: 143-164

Oksanen J, Blanchet F G, Kindt R, Legendre P, Minchin P R, O'Hara R B, Simpson G L, Solymos P, Stevens M H H, Wagner H (2013). Vegan: Community Ecology Package.

Passy SI (2007) Diatom ecological guilds display distinct and predictable behaviour along nutrient and disturbance gradients in running waters. Aqua Bot 86: 171-178.

Pieterse AJH, Van Zyl JM (1988) Observations on the relation between phytoplankton diversity and environmental factors in the Vaal River at Balkfontein, South Africa. Hydrobiologia 169: 199-207. doi: 10.1007/BF00007311

Pillar VD (1999) On the identification of optimal plant functional types. J Veg Sci 10: 631-640. doi: $10.2307 / 3237078$

R Core Team (2013) R: A language and environment for statistical computing. R Foundation for statistical computing, Vienna, Australia

Reynolds CS (1997) Vegetation Process in the pelagic: a model for ecosystem theory. Excellence in Ecology. Ecology Institute, Luhe

Reynolds CS, Huszar V, KruK C, Naselli-Flores L, Melo S (2002) Towards a functional classification of the freshwater phytoplankton. J Plankton Res 24: 417-428. doi: 10.1093/plankt/24.5.417

Reynolds CS, Descy DP, Padisak J (1994) Are phytoplankton dynamics in rivers so different from those in shallow lakes? Hydrobiologia 289: 1-7. doi: 10. 1007/BF00007404

Reynolds CS (2006) Ecology of phytoplankton. Cambridge University Press, Cambridge

Salmaso N, Padisak J (2007) Morpho-functional groups and phytoplankton development in two deep lakes (Lake Garda, Italy and Lake Stechlin, Germany). Hydrobiologia 578: 97-112. doi: 10. 1007/s10750-0060437-0

Salmaso N, Naselli-Flores L, Padisak J (2015) Functional classifications and their application in phytoplankton ecology. Freshwater Biol 60: 603-619. doi: 10. 1111/fwb.12520

Shipley B, Keddy PA, Moore DRJ, Lemky K (1989) Regeneration and establishment strategies of emergent macrophytes. J Ecol 77: 1093-1110. doi: 10. 2307/2260825

Smol JP, Charles DF, Whitehead DR (1984) Mallomonadacean (Chrysophyceae) assemblages and their relationships with limnological characteristics in 38 Adirondack (New York) lakes. Candian Journal of Botany, 62: 911-923. doi: 10. 1139/b84-130

Sommer U, Gliwicz ZM, Lampert W, Duncan A (1986) The PEG-model of seasonal succession of planktonic events in fresh waters. Archic fur Hydrobiologie 106: 433-471.

Usseglio-Polatera P, Bournaud M, Richoux P, Tachet H (2000) Biological and ecological traits of benthic freshwater macroinvertebrates: relationships and definition of groups with similar traits. Freshwater Biol 43: 175-205. doi: 10. 1046/j.1365-2427.2000.00535.x 
Van Dam H, Mertens A, Sinkeldam J (1994) A coded checklist and ecological indicator values of freshwater diatoms from the Netherlands. Netherland Journal of Aquat Ecol 28: 117-133.

Wang G, Xia J (2010) Improvement of SWAT2000 modelling to assess the impact of dams and sluices on streamflow in the Huai River basin of China. Hydrol Proc 24: 1455-1471. doi: 10.1002/hyp.7606

Weithoff G (2003). The concepts of 'plant functional types' and 'functional diversity'in lake phytoplanktona new understanding of phytoplankton ecology?. Freshwater Biol 48: 1669-1675. doi: 10.1046/j.13652427.2003.01116.x

Yamamoto M, Hayashi K (2015) Clustering of multivariate binary data with dimension reduction via $\mathrm{L}_{1}$ regularized likelihood maximization. Pattern Recogn 48: 3959-3968. doi: 10.1016/j.patcog.2015.05.026

Zhu W, Pan Y, Tao J, Li X, Xu X, Wang Y, Wang Q (2013) Phytoplankton community and succession in a newly man-made shallow lake, China. Aquat Ecol 47: 137-147. doi: 10. 1007/s10452-013-9430-7

Zhu W, You Q, Pang W, Pan Y, Wang Y, Wang Q (2015) Phytoplankton community distribution pattern in a large river basin, China. Ecol Sci 37: 136-147

Table 1. The data format for identifying phytoplankton associations

\begin{tabular}{llllllll}
\hline Sites/Species & G1 & G2 & G3 & G4 & G5 & G6 & $\ldots .$. \\
\hline S1 & 1 & 0 & 1 & 1 & 0 & 0 & \\
S2 & 0 & 1 & 0 & 0 & 1 & 0 & \\
S3 & 1 & 1 & 1 & 0 & 0 & 0 & \\
S4 & 0 & 0 & 1 & 0 & 1 & 1 & \\
S5 & 0 & 0 & 0 & 1 & 0 & 1 & \\
S6 & 0 & 1 & 1 & 0 & 1 & 0 & \\
S7 & 1 & 0 & 0 & 1 & 1 & 1 & \\
S8 & 1 & 0 & 0 & 1 & 0 & 1 & \\
S9 & 0 & 1 & 0 & 0 & 1 & 1 & \\
S10 & 0 & 1 & 1 & 0 & 1 & 0 & \\
S11 & 0 & 0 & 1 & 0 & 0 & 1 & \\
\hline
\end{tabular}

Table 2. Calculate the frequency of associations

\begin{tabular}{llll}
\hline Phytoplankton associations & Site & Number of sites & Support (\%) \\
\hline G1,G3 & S1,S3 & 2 & 18 \\
G1,G2 & S3 & 1 & 9 \\
G3,G5 & S4,S6,S10 & 3 & 27 \\
G1,G2,G3 & S3 & 1 & 9 \\
G2,G3,G5 & S6,S10 & 2 & 18 \\
G1,G4,G5,G6 & S7 & 1 & 9 \\
\hline
\end{tabular}

Table 3. Calculate the confidence of associations

\begin{tabular}{llll}
\hline $\begin{array}{l}\text { Phytoplankton } \\
\text { associations (X and Y) }\end{array}$ & Number of $\operatorname{sites}(\mathrm{X})$ & $\begin{array}{l}\text { Number of sites }(\text { Both X } \\
\text { and } \mathrm{Y})\end{array}$ & $\begin{array}{l}\text { Confidence (Both X and } \\
\mathrm{Y} / \mathrm{X})\end{array}$ \\
\hline G1andG3 & 4 & 2 & 0.5 \\
G1and G2 & 4 & 1 & 0.25 \\
G3and G5 & 6 & 3 & 0.5
\end{tabular}




\begin{tabular}{llll}
\hline $\begin{array}{l}\text { Phytoplankton } \\
\text { associations (X and Y) }\end{array}$ & Number of sites (X) & $\begin{array}{l}\text { Number of sites (Both X } \\
\text { and Y) }\end{array}$ & $\begin{array}{l}\text { Confidence (Both X and } \\
\text { Y /X) }\end{array}$ \\
\hline G1,G2and G3 & 1 & 1 & 1 \\
G2and G3,G5 & 5 & 2 & 0.4 \\
G1,G4and G5,G6 & 3 & 1 & 0.33 \\
\hline
\end{tabular}

Table 4. The summary of phytoplankton taxa frequency in HRB and Dishui Lake

\begin{tabular}{|c|c|}
\hline Taxa & Frequency $(\%)$ \\
\hline \multicolumn{2}{|l|}{ Huaihe River $\operatorname{Basin}(\mathrm{n}=217)$} \\
\hline Cryptomonas erosa (C.erosa) & 88 \\
\hline Cyclotella meneghiniana (C. meneghiniana) & 82 \\
\hline Scenedesmus quadricauda (S. quadricauda) & 78 \\
\hline Chroomonas acuta (C. acuta) & 74 \\
\hline Navicula cryptocephala (N. cryptocephala) & 71 \\
\hline Oscillatoria agardhii (O. agardhii) & 63 \\
\hline Nitzschia palea (N. palea) & 59 \\
\hline Chromulina sp. & 58 \\
\hline Chlamydomonas globosa (C. globosa) & 57 \\
\hline Synedra sp. & 53 \\
\hline Cryptomonas ovata (C.ovata) & 52 \\
\hline Gomphonema sp. & 45 \\
\hline Nitzschia amphibia (N.amphibia) & 45 \\
\hline Cocconeis placentula (C. placetula) & 39 \\
\hline Oocystis lacustis (O. lacustis) & 38 \\
\hline Navicula sp. & 35 \\
\hline Pseudanabaena sp. & 34 \\
\hline Euglena oxyuris (E. oxyuris) & 34 \\
\hline Achnanthes sp. & 32 \\
\hline Carteria sp. & 32 \\
\hline Synedra ulna (S. ulna) & 32 \\
\hline Synedra sp. & 31 \\
\hline Nitzschia sp. & 30 \\
\hline Cymbella tropica (C. tropica) & 28 \\
\hline Aulacoseira granulata (A. granulata) & 28 \\
\hline Phormidum sp. & 27 \\
\hline Synedra acus (S. acus) & 26 \\
\hline Melosira varians (M. varians) & 26 \\
\hline Fragilaria sp. & 25 \\
\hline Nitzschia reversa $(N$. reversa) & 22 \\
\hline Ceratium hirundinella (C. hirundinella) & 20 \\
\hline Closterium sp. & 17 \\
\hline Euglena sp. & 15 \\
\hline Mallomonas sp. & 9 \\
\hline Euglena clavata (E. clavata) & 9 \\
\hline Pandorina morum (P. morum) & 9 \\
\hline Euglena sp. & 7 \\
\hline Dinobryon sp. & 6 \\
\hline Dishui Lake(n=70) & \\
\hline Chlamydomonas globosa (C. globosa) & 99 \\
\hline
\end{tabular}




\begin{tabular}{|c|c|}
\hline Taxa & Frequency $(\%)$ \\
\hline Chromulina pygmaea (C. pygmaea) & 93 \\
\hline Scenedesmus quadricauda (S. quadricauda) & 91 \\
\hline Navicula sp. & 91 \\
\hline Ankistrodesmus angustus(A. angustus) & 84 \\
\hline Chaetoceros muelleri (C. muelleri) & 83 \\
\hline Synedra acus (S. acus) & 83 \\
\hline Oocystis lacustis (O. lacustis) & 81 \\
\hline Chroomonas acuta (C. acuta) & 80 \\
\hline Cocconeis placentula (C. palcetula) & 76 \\
\hline Euglena sp. & 69 \\
\hline Oscillatoria agardhii (O. agardhii) & 67 \\
\hline Gymnodinium sp. & 66 \\
\hline Cryptomonas erosa (C. erosa) & 63 \\
\hline Ochroomonas sp. & 59 \\
\hline Cyclotella meneghiniana (C. meneghiniana) & 59 \\
\hline Aulacoseira granulata $($ A. granulata $)$ & 56 \\
\hline Nitzschia sp. & 54 \\
\hline Carteria sp. & 41 \\
\hline Amiphiprora sp. & 39 \\
\hline Cryptomonas ovata (C.ovata) & 33 \\
\hline Cyclotella sp. & 29 \\
\hline Melosira varians ( $M$. varians) & 29 \\
\hline
\end{tabular}

Table 5. The phytoplankton associations composition in HRB and Dishui Lake (R:River;L:Lake)

\begin{tabular}{|c|c|c|c|c|}
\hline Number+group & Taxa 1 & Taxa 2 & Taxa 3 & Habitat template \\
\hline R01-1 & C. ovata & C. erosa & & pollution, poor light, lentic \\
\hline R02-1 & Chromulina sp. & C. erosa & & oligotrophic-mesotrophic + pollution \\
\hline R03-2 & Chromulina sp. & C. meneghiniana & & oligotrophic-mesotrophic+ silica-rich, low P \\
\hline R04-3 & N. palea & C. meneghiniana & & shallow turbid + silica-rich, low $\mathrm{P}$ \\
\hline R05-2 & N. palea & C. erosa & & shallow turbid + pollution \\
\hline R06-2 & N. cryptocephala & C. acuta & C. erosa & shallow turbid + pollution \\
\hline R07-2 & C. meneghiniana & N. cryptocephala & C. erosa & silica-rich+shallow turbid + pollution \\
\hline R08-2 & C. acuta & C. globosa & C.meneghiniana & meso-eutrophic+organic and inorganic nutrien \\
\hline R09-1 & C.acuta & C. globosa & C. erosa & meso-eutrophic+pollution \\
\hline $\mathrm{R} 10-2$ & C. meneghiniana & C. acuta & C. erosa & silica-rich, low $\mathrm{P}+$ meso-eutrophic \\
\hline $\mathrm{R} 11-2$ & C. meneghiniana & C. globosa & C. erosa & silica-rich, low $\mathrm{P}+$ meso-eutrophic \\
\hline $\mathrm{R} 12-2$ & C. meneghiniana & O. agardhii & C. erosa & silica-rich, low $\mathrm{P}+$ meso-eutrophic \\
\hline L01-2 & O. lacustis & C. globosa & & p-limit + meso-eutrophic \\
\hline L02-2 & S. acus & C. globosa & & shallow turbid + meso-eutrophic \\
\hline L03-2 & A. angustus & C. pygmaea & & clear, mixed + shallow oligotrophic brackish \\
\hline L04-2 & A. angustus & C. globosa & & clear, mixed + meso-eutrophic \\
\hline L05-2 & C. muelleri & C. globosa & & brackish, high NP+ meso-eutrophic \\
\hline L06-3 & S. quadricauda & Navicula sp. & & shallow, mixed + turbid shallow \\
\hline L07-2 & S. quadricauda & C. pygmaea & & shallow mixed + shallow oligotrophic brackish \\
\hline L08-2 & S. quadricauda & C. globosa & & shallow mixed + meso-eutrophic \\
\hline L09-2 & Navicula sp. & C. pygmaea & & turbid shallow + shallow oligotrophic brackish \\
\hline L10-2 & Navicula sp. & C. globosa & & turbid shallow + meso-eutrophic \\
\hline L11-1 & C. pygmaea & C. globosa & & shallow oligotrophic brackish + meso-eutrophic \\
\hline
\end{tabular}




\begin{tabular}{lllll}
\hline Number+group & Taxa 1 & Taxa 2 & Taxa 3 & Habitat template \\
\hline L12-2 & Navicula sp. & S. quadricauda & C. pygmaea & turbid+shallow mixed+shallow oligotrophic bre \\
L13-2 & Navicula sp. & S. quadricauda & C. globosa & turbid shallow+ shallow mixed+ meso-eutroph \\
L14-2 & S. quadricauda & C. pygmaea & C. globosa & shallow+oligotrophic brackish+meso-eutrophic \\
L15-2 & Navicula sp. & C. pygmaea & C. globosa & turbid+shallow +oligotrophic brackish+meso-eu \\
\hline
\end{tabular}

Figure 1. The map of China showing the location of HRB and the HRB showing all sampling stations of phytoplankton

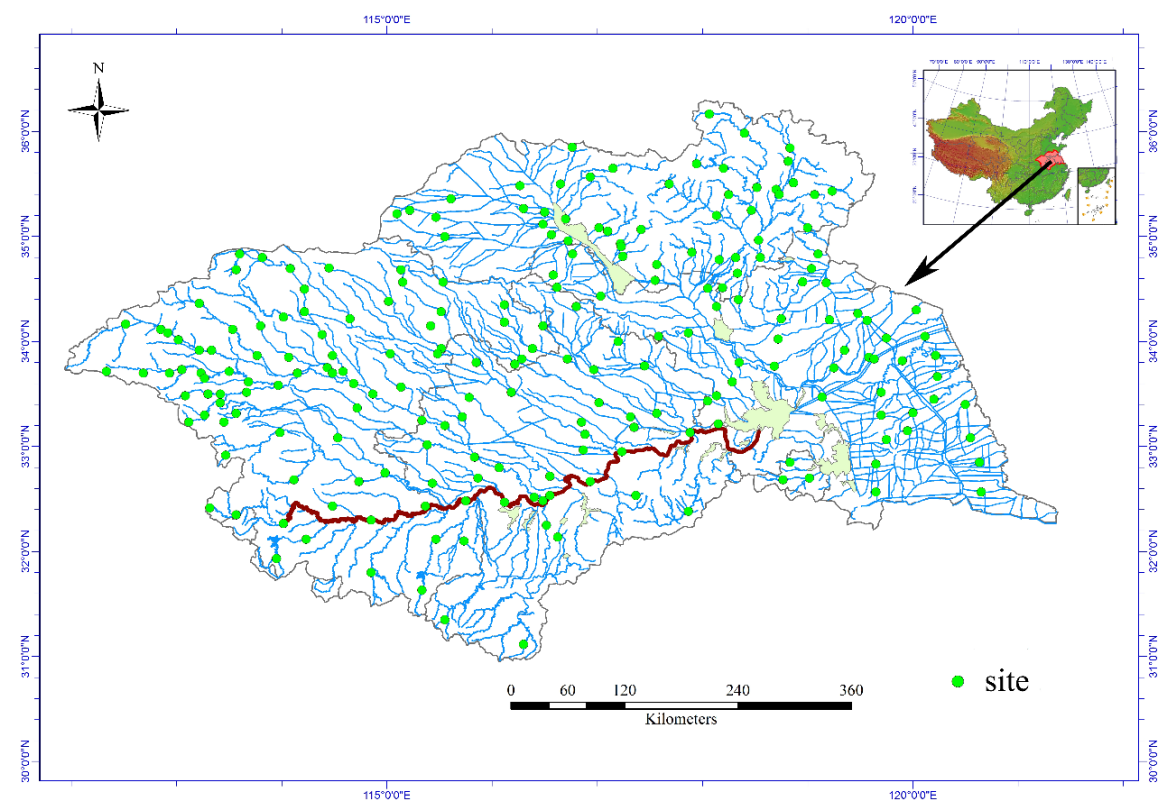

Figure 2. The map of Shanghai (a) and Dishui Lake (b) showing all sampling stations of phytoplankton
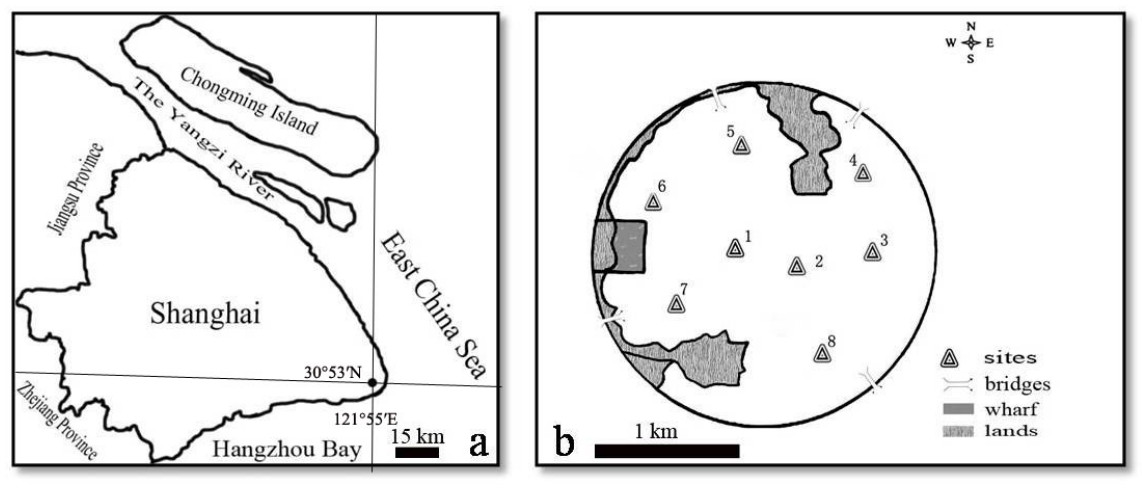

Figure 3. The RDA plot of 12 phytoplankton associations and environmental variables in HRB. (DO: Dissolved Oxygen; TN: Total Nitrogen; NP:TN/TP ratio; Cond: Conductivity; phytoplankton association codes are in Table 5) 


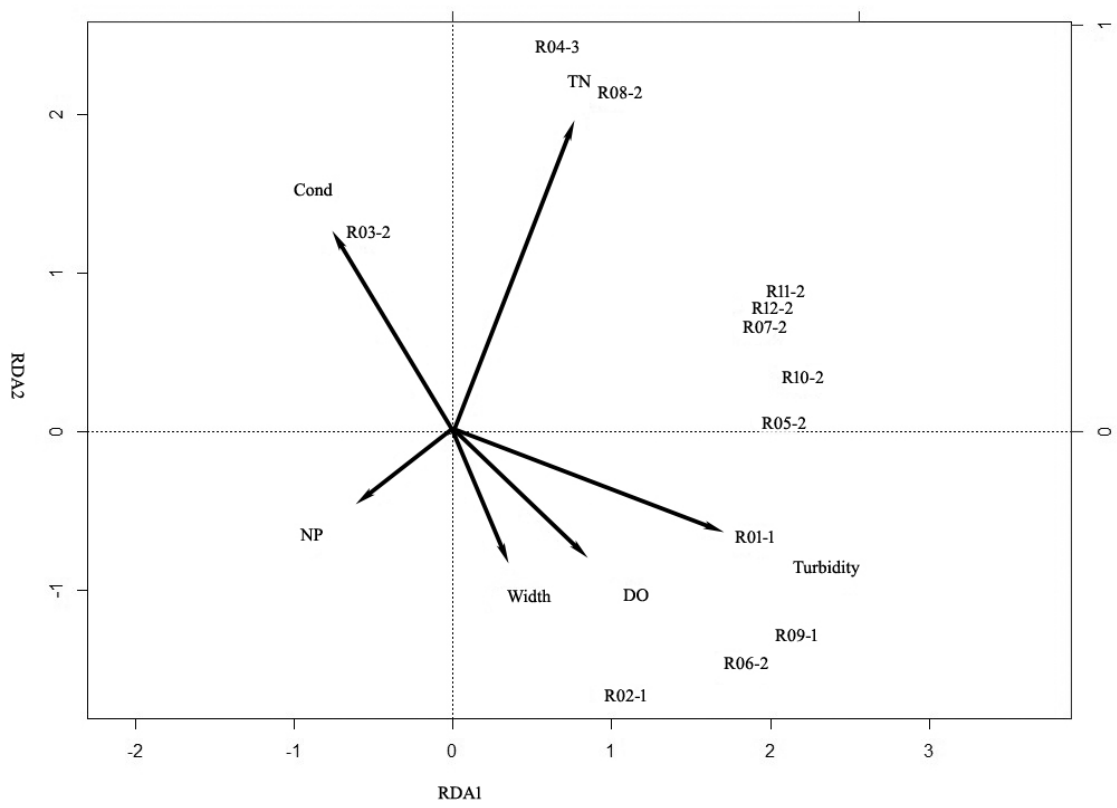

Figure 4. The RDA plot of 15 phytoplankton associations and environmental variables in Dishui Lake ( Sal: Salinity; phytoplankton association codes are in Table 5)

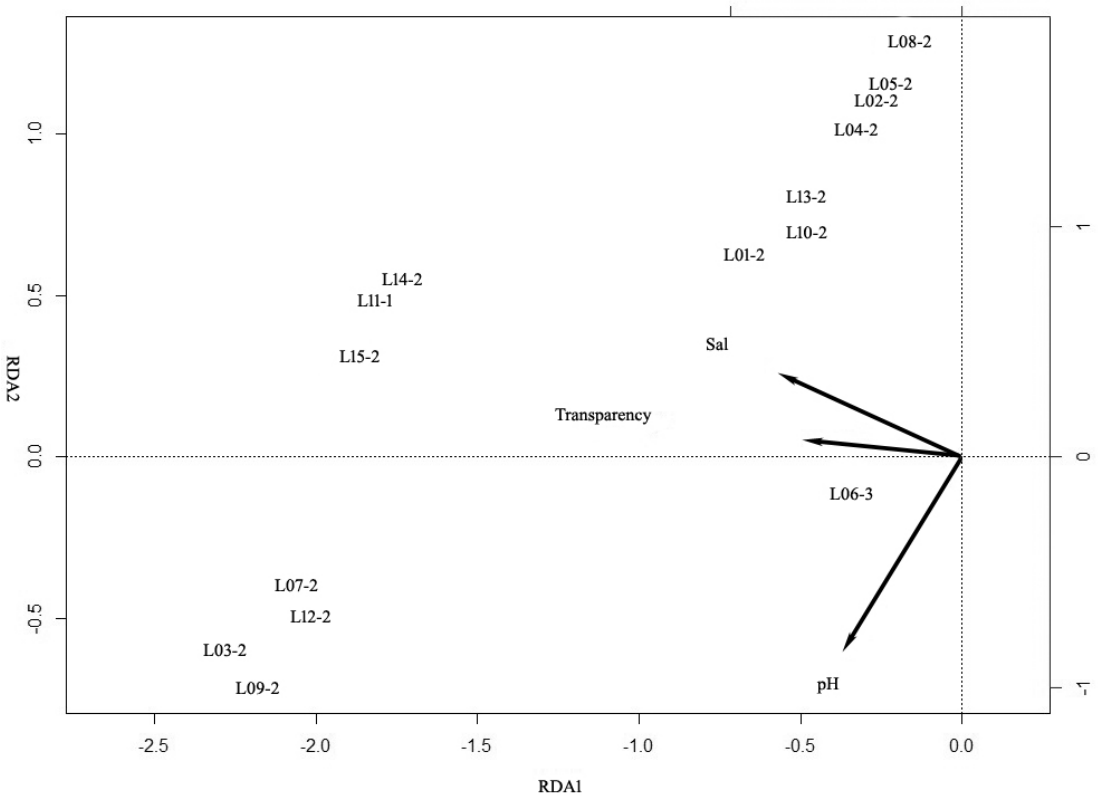

